\title{
Effectiveness of Krishna Laddoo in treating malnutrition in anganwadi children
}

\section{Corresponding author:}

Dr. Madhura Karguppikar, Resident, Department of Paediatrics, Krishna Institute of Medical Sciences, Karad Maharashtra, India, 415539, tel: +91-09742969280, email: madhurakarguppikar@gmail. com
Medical Research Journal 2019; Volume 4, Number 1, 46-51 DOI: 10.5603/MRJ.a2019.0006 Copyright (C) 2019 Via Medica ISSN 2451-2591

\begin{abstract}
Background: This was a prospective pilot study to estimate the burden of malnutrition in the age group of 2.5-5 years and to evaluate the usefulness of dietary changes in them. This research was conducted by the Department of Paediatrics Krishna Institute of Medical Sciences, Karad in selected Anganwadi at Rethare Bk., This study was undertaken to combat the issue of malnutrition of children's in the age group of 2.5 to 5 years. According to WHO-Moderate Acute Malnutrition is defined by a weight-for-height indicator between -3 and -2 z-scores (standard deviations) of the international standard or by a mid-upper arm circumference (MUAC) between $11 \mathrm{~cm}$ and $12.5 \mathrm{~cm}$. Severe Acute Malnutrition is defined by very low weight for height below -3z scores of the median WHO growth standards by visible severe wasting. The children identified with SAM \& MAM were started on a high nutrition laddu called the Krishna laddu which was specially designed by the Krishna Institute of Medical Sciences Deemed To be University to cater to the deficiencies in malnourished children. The aim of the study was to determine the effectiveness of Krishna laddu in treating malnutrition in children aged between 2.5-5 years.

Methods: This was a prospective study. Total of 43 children attending the 2 selected anganwadi adopted by the Krishna Institute of Medical Sciences, Karad (aged between 2.5-5 years) were screened for malnutrition and graded according to Severe Acute Malnutrition and Moderate Acute Malnutrition and were given Krishna Laddu on a daily basis. Their anthropometry was serially recorded on a weekly basis over a period of 1.5 years to determine the effectiveness of the Krishna Laddu in improving the nutritional status in the malnourished children

Results: The prevalence rate of malnutrition was 23\% (21\% MAM and 2\% SAM) in the children aged between 2.5-5 years the given population which was reduced to 8\% MAM after their diet was added with Krishna Laddu. Conclusions: Krishna Laddu proved to be beneficial in the nutritional rehabilitation of malnourished children. The highlights of this research were: 1) early identification of malnutrition 2) prompt initiation of a nutritious diet to improve outcome 3) serial monitoring of these children to plot the outcome. 4) All the ingredients used for making the laddu are easily available in the kitchen. 5) The preparation is low cost, making it feasible for use in any setup.

Keywords: Krishna Laddu, SAM, MAM, MUAC.
\end{abstract}

Med Res J 2019; 4 (1): 46-51

\section{Introduction}

Malnutrition kills 5 million children every year. Adequate nutrition is critical to child development, especially in the formative years, from 2.5 to 5 years of as it can shape the child's growth, health and development. At this age, children are particularly vulnerable to growth retardation, micronutrient deficiencies and common childhood illnesses such as malnutrition, diarrhoea, pneumonia and acute respiratory infections. In developing countries, children are vulnerable to malnutrition because of low dietary intakes, high incidence of infectious diseases, lack of appropriate care and inequitable distribution of food within the household. Hence this study is very important.

According to $\mathrm{WHO}$, India contributes to about $21 \%$ of the global burden of child deaths. The under-five mortality rate (U5MR) for India in 2011 has been es- 
timated as 55 per 1000 live births [1]. Malnutrition is the direct or indirect cause in up to $50 \%$ under-five deaths. About $25 \%$ of children under-five in the world are underweight, and in India, the underweight prevalence rate is at $43 \%$. Also, the prevalence of wasting in India is about $20 \%$, requiring an urgent response [2-3]. According to the NFHS-3 in the year 2015-2016, the trends in children's nutritional status in India was $38 \%$ were stunted (too short for age), $19 \%$ were wasted (too thin for height), 46\% were underweight (too thin for age) [4]. These figures are certainly alarming and warrant intervention.

The Krishna Laddu Project is a well-intentioned attempt at improving the health of children living in a rural background and also for peoples living in poor condition. The approach is innovative, though there have been similar projects and locally focused. Additionally, the project design is largely solid and well thought out. The laddus are a well-chosen and thought-out supplement, they reduce the deficit in the child's nutrition by giving a significant supplement to both the calorie and protein intake. Their simple recipe (requiring minimal cooking time) and long-lasting nature make them very well suited to storage. Additionally, the use of readily available, cheap ingredients is excellent. Also, the dietary counselling contributed to the improvement in the nutritional status of the children.

\section{Materials and methods}

The project was carried out over a period of 18 months with their weekly follow-up. A team consisting of the paediatric resident, houseman and a nurse visited 2 Anganwadi's at Rethare Bk. weekly to serially record the weight, height and MUAC of the children between 2.5-5 years who were enrolled at their Anganwadi.

Anganwadi is a novel concept by the Government of India which serves as the first informal education medium and a day care centre for children in this age group of 2.5-5 years. The children were then categorised into SAM/MAM according to WHO criteria.
Krishna Laddu, an innovation of the Krishna Institute of Medical Sciences, Karad was given to each of the SAM/MAM children daily. Friday of each week was chosen by for the anthropometry measurement (weight recorded weekly and height and mid-upper arm circumference recorded every month) and for handing over the laddus for coming week to the health workers at the Anganwadi. The progress of the children was plotted on the WHO growth charts to note the changes in the anthropometry.

The laddoo was a supplement that the children received in addition to the meal consumed at the anganwadi. Each day of the week had different meals like dal khichadi, upma, kheer etc. prepared by the anganwadi workers so as to give about 300 calories and 8-gram proteins to the child.

The laddoo scored better than these meals as the children equated the idea of getting a laddoo to a treat and also because the laddoo, if not finished by the child in one go, could be stored and offered again after a while. This could not be done with the meals as they would turn cold and would not be appetizing to the child anymore.

The ingredients of the laddu were dry roasted before using them. This increased the shelf life of the laddu. Also, at the anganwadis, the laddus were stored in air tight containers to prevent the moisture from making them less palatable to the children. This contributed to keeping the taste and texture of the laddus unaltered for about a week.

The project also served the purpose of a health check-up by the pediatric resident on weekly basis. Issues like de-worming, need for sanitation and hygienic situation, faulty cooking practices, advice with regard to child rearing and nutrition were addressed on the $4^{\text {th }}$ Friday of each month by holding a meeting with the parents under the project. The most important part of these sessions was the dietary counselling regarding a balanced diet and educating the mothers about what diet could help in proper nourishment of their children.

It is worth mentioning here that during the course of the study, the anganwadi workers were interviewed

Contents of the Krishna Laddu

\begin{tabular}{lccccccc}
\hline Ingredient & $\begin{array}{c}\text { Weight } \\
(\mathbf{g m s})\end{array}$ & $\begin{array}{c}\text { Calories } \\
\mathbf{( g m s )}\end{array}$ & $\begin{array}{c}\text { Proteins } \\
\mathbf{( g m s )}\end{array}$ & $\begin{array}{c}\text { Carbs } \\
\text { (gms) }\end{array}$ & $\begin{array}{c}\text { Fat } \\
\text { (gms) }\end{array}$ & $\begin{array}{c}\text { Calcium } \\
\text { (gms) }\end{array}$ & $\begin{array}{c}\text { Iron } \\
\text { (gms) }\end{array}$ \\
\hline Soyabean powder & 15 & 64.8 & 4.85 & 2.85 & 2.95 & 36 & 1.56 \\
Ragi powder & 05 & 16.4 & 0.36 & 3.6 & 0.06 & 17.2 & 0.915 \\
Chana dal powder & 05 & 18.0 & 0.85 & 0.28 & 0.26 & 10.1 & 0.23 \\
Groundnut & 05 & 28.2 & 2.0 & 0.27 & 3.71 & 4.42 & 0.31 \\
Jaggery & 20 & 76.6 & 0.08 & 19 & 0.02 & 16 & 2.28 \\
Groundnut oil & 10 & 90 & - & - & 10 & - & - \\
Total & 60 & 294 & 10 & 26 & 17 & 84 & 4.575 \\
\hline
\end{tabular}


in depth about the food habits of these children. They said that many parents took the meals provided at the anganwadis and the additional laddoo provided by us as a substitute for the home meals. This was a major fallacy as the child was deprived of their meals at home. The mothers were explained again that this was only a supplement and not a substitute for the food that the child received at home.

\section{Ethical Considerations}

As an intervention study involving children, the Laddu Project was presented before the Ethical Committee and permission was obtained from the Ethical Committee for the same.

\section{Statistical Analysis:}

Descriptive statistics were used to describe the age and sex distribution of the children. We created binary outcome variables for the diagnosis of severe wasting using MUAC and Weight for height $Z$ scores as described in the methods section. Proportions and 95\% confidence intervals were computed to allow comparisons between indicators. The ages of the children were dichotomized to correspond to categories usually used in field nutrition programmes: young (age $<24$ months), and older children (age $\geq 24$ months). The prevalence percentage was calculated as per cut-off points of WHO \& NFHS. The association was calculated using ANOVA \& Student t-test. Data were analysed using SPSS 20.0 for Windows statistical package for social science (International Business Machines Corporation, INDIA).

\section{Results}

43 children enrolled at the 2 anganwadis, adopted by KIMSDU, were included in the study, age group was of $2.5-5$ years i.e. 30 to 60 months, maximum 21 (49\%) children's were in the age group of 51-60 months, $13(30 \%)$ children's were in the age group of $41-50$ months and $9(21 \%)$ children's were in
Table 1. Age \& sex wise distribution of demographic variables

\begin{tabular}{lcc}
\hline Demographic Variables & $\begin{array}{c}\text { No. } \\
\text { of children's }\end{array}$ & $\%$ \\
\hline Age in Months & 9 & 21 \\
$31-40$ & 13 & 30 \\
$41-50$ & 21 & 49 \\
$51-60$ & & \\
Sex & 19 & 44 \\
Boys & 24 & 56 \\
Girls & & \\
\hline
\end{tabular}

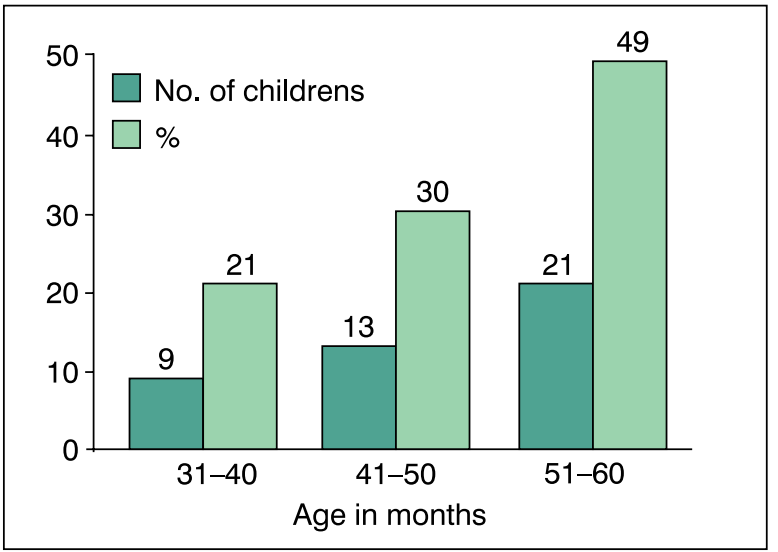

Figure 1. Graphical distribution of age wise distribution

the age group of 31-40 months. According to sex out of $43(100 \%)$ children's max. $24(56 \%)$ were girls and 19 (44\%) were boys which is shown in Table.1 and Figure 1. and 2.

Here, the percent prevalence in overall $43(100 \%)$ children's was calculated as per age group of 3140 months, 41-50 months \& 51-60 months also as per stunting <-2SD (Moderate Class) 52.2\%, 53.5\%, 52.7\% respectively, as per stunting < -3SD (Severe Class) $21 \%, 22.2 \%, 21.5 \%$ respectively, as per wasting $<-2$ SD (Moderate Class) 10.1\%, 10.4\%, 8.4\% respectively, as per wasting $<-3 \mathrm{SD}$ (Severe Class) $0.7 \%, 0.5 \%, 0 \%$, as

Table 2. Prevalence of Undernutrition among Rural Pre-school Children's

\begin{tabular}{lccccccc}
\hline $\begin{array}{l}\text { Age Group } \\
\text { (in months) }\end{array}$ & No. & \multicolumn{5}{c}{ Per cent Prevalence of Undernutrition } \\
\cline { 2 - 7 } & & \multicolumn{2}{c}{$\begin{array}{c}\text { Stunting } \\
\text { (Low height for age) }\end{array}$} & $\begin{array}{c}\text { Wasting } \\
\text { (Low weight for-Height) }\end{array}$ & $\begin{array}{c}\text { Underweight } \\
\text { (Low weight for age) }\end{array}$ \\
\cline { 2 - 8 } & & <-2SD & <-3SD & <-2SD & <-3SD & <-2SD & <-3SD \\
\hline $31-40$ & 9 & 52.2 & 21 & 10.1 & 0.7 & 4.7 & 2.3 \\
$41-50$ & 13 & 53.5 & 22.2 & 10.4 & 0.5 & 7 & 0 \\
$51-60$ & 21 & 52.7 & 21.5 & 8.4 & 0 & 9.3 & 0 \\
\hline
\end{tabular}




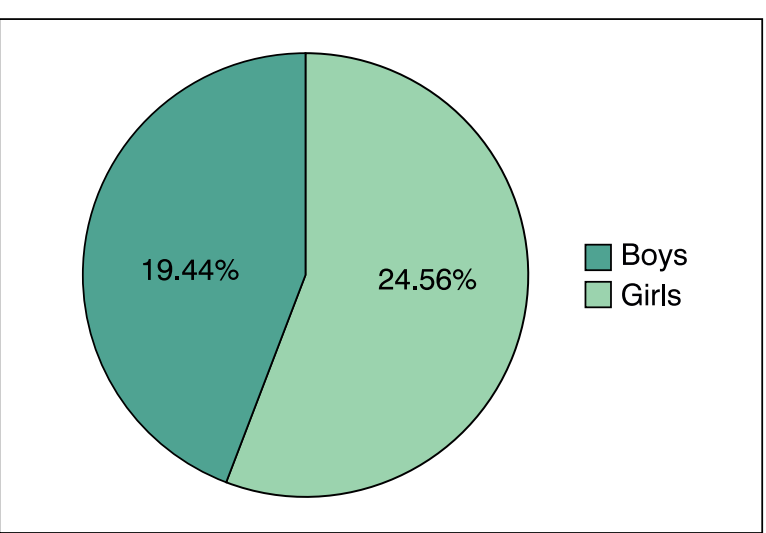

Figure 2. Graphical distribution of Sex wise distribution

per underweight $<-2$ SD (Moderate Class) 4.7\%, 7\%, $9.3 \%$ respectively, as per underweight $<-3$ SD (Severe Class) $2.3 \%, 0 \%, 0 \%$ respectively. Shown in Table.2

Among all $43(100 \%)$ children's maximum 4 (9\%) children's age group of 51-60 months were found in MAM, 3 (7\%) children's with age group of 41-50 months were found in MAM and $2(5 \%)$ children's were found in MAM and only 1 (2\%) with age group of $31-40$ months

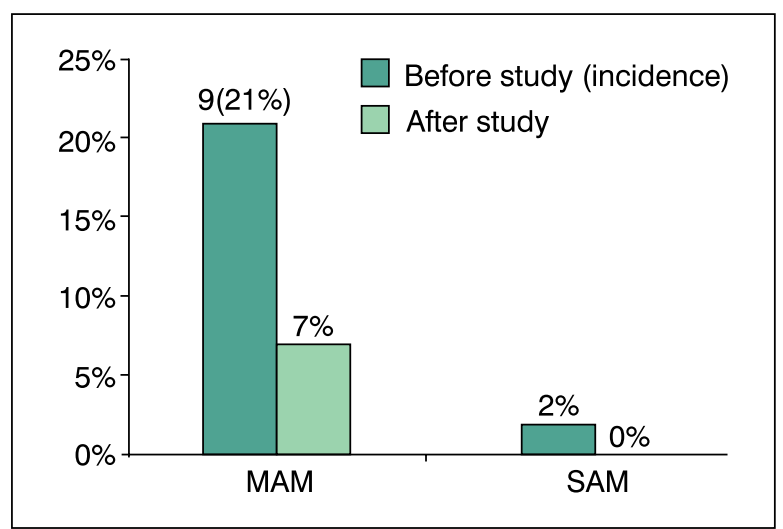

Figure 3. Graphical representation of study prevalence

were found in SAM. The prevalence of moderate acute malnutrition was $21 \%$ and severe acute malnutrition was $2 \%$. Shown in Table 3.

Association between age group vs. different study variables such as HAZ, WAZ and MUAZ was shown in Table 4. Association between sex and different study variables such as HAZ, WAZ and MUAZ was shown in Table 5.

Table 3. Distribution of prevalence of malnutrition

\begin{tabular}{lcccc}
\hline $\begin{array}{l}\text { Age-Group } \\
\text { (in months) }\end{array}$ & No. & $\begin{array}{c}\text { No Malnutrition } \\
\text { (\%) }\end{array}$ & $\begin{array}{c}\text { Moderate Acute } \\
\text { Malnutrition (\%) }\end{array}$ & $\begin{array}{c}\text { Severe Acute Malnutrition } \\
\text { (\%) }\end{array}$ \\
\hline $31-40$ & 9 & $6(14)$ & $3(7)$ & $1(2)$ \\
$41-50$ & 13 & $10(23)$ & $2(5)$ & $0(0)$ \\
$51-60$ & 21 & $17(40)$ & $4(9)$ & $0(0)$ \\
Total & 43 & $33(77)$ & $9(21)$ & $1(2)$ \\
\hline
\end{tabular}

Table 4. Association between different age groups

\begin{tabular}{|c|c|c|c|c|c|c|c|c|c|}
\hline \multirow{2}{*}{$\begin{array}{l}\text { Study } \\
\text { Variable } \\
\text { Age Group } \\
\text { (in months) }\end{array}$} & \multicolumn{3}{|c|}{ Mean Z-Score } & \multicolumn{3}{|c|}{ Standard Deviation } & \multirow[t]{2}{*}{ F-value } & \multirow[t]{2}{*}{ P-value } & \multirow[t]{2}{*}{ Inference } \\
\hline & $31-40$ & $41-50$ & $51-60$ & $31-40$ & $41-50$ & $51-60$ & & & \\
\hline $\mathrm{HAZ}$ & -1.71 & -2.4 & -2.1 & 1.28 & 1.42 & 1.5 & 0.6161 & 0.5451 & NS \\
\hline WAZ & -1.41 & -1.79 & 1.1 & 1.2 & 1 & 0.88 & 41.586 & $<0.0001$ & $S$ \\
\hline MUAZ & -1.63 & -1.57 & 0.87 & 0.9 & 0.87 & 0.67 & 0.01454 & 0.9856 & NS \\
\hline
\end{tabular}

Table 5. Association between different sex groups

\begin{tabular}{|c|c|c|c|c|c|c|c|}
\hline \multirow{2}{*}{$\begin{array}{l}\text { Study variable } \\
\text { Sex }\end{array}$} & \multicolumn{2}{|c|}{ Mean Z-Score } & \multicolumn{2}{|c|}{ Standard deviation } & \multirow[t]{2}{*}{ t-value } & \multirow[t]{2}{*}{ P-value } & \multirow[t]{2}{*}{ Inference } \\
\hline & Boys & Girls & Boys & Girls & & & \\
\hline HAZ & -2.08 & -1.78 & 1.23 & 1.5 & 4.403 & 0.0001 & $S$ \\
\hline WAZ & -1.49 & -1.53 & 0.97 & 0.49 & -2.928 & 0.0055 & $S$ \\
\hline MUAZ & -1.59 & -1.52 & 0.81 & 0.65 & 0.7176 & 0.47 & NS \\
\hline
\end{tabular}


Table 6. Prevalence of malnutrition among study population

\begin{tabular}{lcc}
\hline Prevalence & MAM & SAM \\
\hline Before Study & $21 \%$ & $2 \%$ \\
After Study & $8 \%$ & $0 \%$ \\
\hline
\end{tabular}

\section{Discussion}

The results of this study are deduced and they are discussed below. They are divided into criteria of relevance, effectiveness, efficiency, impact and sustainability. 'Relevance' considers how well the Laddu Project is suited to tackling malnutrition in the Rethare Bk. context. 'Effectiveness' focuses on the goals achieved by the Laddu Project. 'Efficiency' considers whether the project's method is efficient in its processes. 'Impact' looks at the wider effect that the project can have on the community. Finally, 'Sustainability' covers the project's longevity and potential expansion.

Likewise, similar studies have been done in India and outside India which is very important for the assessment of malnutrition. In a cross-sectional study, of 309 Kamar Tribal Children aged 4-12 years to assess the nutritional status [6]. The result was more than $90 \%$ of children in the age group 4-12 years suffered from underweight which was comparatively lower in 7-9 and 10-12 years age group children. $84.51 \%$ percent of boys suffered from stunting which was much higher than girls (47.54\%) [6]. The study concluded there was a widespread prevalence of malnutrition among tribal children and an urgent dietary intervention programme was necessary [7].

Another study was community-based and a cross-sectional survey carried out in preschool children of the Gond community in Madhya Pradesh. The result of the study showed more than $60 \%$ of children were underweight. Unhygienic personal habits and adverse cultural practices relating to child rearing, breastfeeding and weaning were also prevalent among them [8]. These factors were thought about in the initiation of our study and counselling was effectively carried out to make the mothers aware of the right child-rearing practices.

A total of 6531 Punjabi children in the age group 1-5 years were measured in a cross-sectional study for assessing malnutrition. The percentage of children who were underweight, stunted, wasted and having low MUAC for age was 15.04\%, $11.42 \%, 10.76 \%$ and $38.52 \%$ respectively [9].

Of late, there has been intense debate and discussion on how to best intervene to make a change that is both substantial and rapid and various groups of experts have presented strategies to policy makers as to the steps that need to be taken for both preventing malnutrition and treating its most severe forms [10]. Many locally produced/producible foods that are culturally acceptable and relatively low cost have been used for severe malnutrition cases in India for many decades by reliable academic and medical institutions as well as by non-governmental groups. One of the effective measures was the use of Leaf Protein Mix to improve the protein intake of children affected with Malnutrition [11].

A study on the effects of curd (dahi) and leaf protein concentrate in children with protein-energy malnutrition. The study was conducted in a tertiary hospital at New Delhi, in which 80 moderately and severely malnourished children of age 1-5 years were given either the curd or LPC in addition to the WHO recommended two-step diet for 15 days. The results revealed a change in weight, haemoglobin level and CD4: CD8 and T-cell subpopulation was significant in both the groups after supplementation. The study concluded that curd and LPC, when added to the diet of malnourished children, would accelerate the immune recovery and improve the nutritional status of the affected children [12]. Our study was also based on maximum utilisation of locally available products making it extremely cost effective.

A study done on the health and nutritional status of preschool children of Amritsar district of Punjab were studied. A total of 1,000 children formed the group. Out of the 1000 children examined, 255 (25.5\%) children were found to be suffering from protein-energy malnutrition. $25.18 \%$ of boys and $25.85 \%$ of girls had protein-energy malnutrition [13].

Studies have also shown that the formula advised by the National Institute of Nutrition, Hyderabad specially prepared protein mixtures provided an increase of weight after 22 days to 3 weeks or little later [14].

How does one achieve a balanced diet with plenty of protein where animal protein sources or even legume seeds are too expensive? The Krishna Laddu mix which can be easily made from the local produce is an outstanding source of quality protein and vitamins. It can be made with very little cost, even from ingredients available in the kitchen.

In view of the above facts, we observed that protein-energy malnutrition is one of the 'silent emergencies' seen in children of age 0-5 yrs of age. The treatment lies in providing malnourished children with energy and protein-rich foods so that there is adequate weight gain. These foods can be prepared from the usual home diets. The home diets may provide insufficient energy and protein to the child leading to further deterioration in the child's nutritional status.

A study was conducted at Delhi regarding malnourishment among the children aged 6 months to 2 years. A total of 1661 children who attended the well baby clinic of UHC, Gokulpur, Delhi during the year 
2000 were studied. The results of the studied showed a total of $1009(60.7 \%)$ children were found malnourished [15].

A cross-sectional study was done to assess the health and nutritional status of children of $0-5$ years age group and to study the influence of various epidemiological factors on health and nutritional status. The study was carried out in randomly selected three wards of Petlad town, district Anand in Gujarat state. The prevalence of underweight was $43.6 \%$. $50.3 \%$ of children were found stunted. Prevalence of wasting was comparatively low of $23.2 \%$ [16].

A study carried out in three backward states, two blocks were selected in each state on the basis of the maximum concentration of the backward community. a total of 80 samples were selected from the 18 blocks making a sum of 1440 samples. $66.2 \%$ of all children of $0-5$ years of age were underweight of which $23.1 \%$ were under grade III and IV, showing the severe extent of malnutrition. The highest number of children in Grades III and IV were from Uttar Pradesh $27.1 \%$ followed by Orissa $22 \%$ and Rajasthan $21.1 \%$. The study also revealed the children were short for age or stunted $32.9 \%$ in the age group below three years [17].

A comparative study to determine the biochemical nutritional indicators among children suffering from protein-energy malnutrition and among the well-nourished children of age group 0-5 yrs at outpatient department and wards of Kanti Children's Hospital, Maharganj Kathmandu, Nepal, and the sample was of 120 children. The results revealed that there were altered biochemical parameters which were related to food intake and biochemical metabolism mandatory during growth and development of children less than five years of age [19].

All of the above studies only substantiate the result of our study and add to the importance of home-based supplements.

\section{Conclusion}

The anthropometry showed a significant improvement in the health status of the children who received the Krishna Laddu as a supplement. The Krishna Laddu reduced the calorie and protein deficit in the malnourished children. Krishna Laddu proved to be beneficial in the highlights of this research were: 1 ) early identification of malnutrition 2) prompt initiation of a nutritious diet to improve outcome 3 ) serial monitoring of these children to plot the outcome. 4) All the ingredients used for making the laddu are easily available in the kitchen. 5) The preparation is low cost, making it feasible for use in any setup.

Additionally, the counselling of the mothers helped in better understanding of hygiene and nutrition.

It would be very interesting to investigate how exactly the Laddu Project could aid the supplementary feeding programme of the ICDS. The laddu could be used as an intervention for nutritional rehabilitation of the malnourished children in a large community too.

\section{References}

1. UNICEF Progress for Children Report, December 2011

2. UNICEF Progress for Children Report. December 2018- Undernutrition- a challenge for India.

3. NCHS/ WHO: Report on Underweight among Under-five children 2000-2007 2007.

4. National Family Health Survey (NHFS-3) National Fact Sheet- India.2015-2016.

5. National Family Health Survey (NFHS-3) Fact Sheet- Karnataka 2015-2016.

6. Mitra Mitrashree, Kumar .P.V et.al: Nutritional Status of Kamar Tribal Children in Chattisgarh: Indian Journal of Pediatrics, April 2007. Volume. : 74.

7. Rao VG, Yadav R, et al. Undernutrition and childhood morbidities. Regional Medical Research Centre for tribal, Jabalpur. Indian Journal of Medical Research Centre. 2004: 43-47.

8. Kaur G, Kang H, Singal P, et al. Nutritional Status : Anthropometric Perspective of Pre-School Children. The Anthropologist. 2017; 7(2): 99-103, doi: 10.1080/09720073.2005.11890898.

9. Working Group for Children Under six: Strategies for Children under Six: Special Article, Economic and Political Weekly. December 2007.

10. Power point Presentation by Jarett Steve: UNICEF 20th September 2008: Ready-to-Use Therapeutic Foods (RUTF): Addressing the Situation of Children with Severe Acute Malnutrition- Production in India.

11. Dewan P, Kaur I, Chattopadhya D, et al. Study on effects of curd and leaf protein concentrate in children with protein energy malnutrition. Indian Journal of Medical Research. 2007: 199-203, doi: 10.1007/springerreference 42288

12. Uppal M, Kumari K. Sidhu. S: Clinical Assessment of Health and Nutritional Status of Scehduled Caste Preschool children of Amritsar: Anthropologist. 2005; 7(3): Pp169.

13. Rao DH, Sharma KV, Kumar S, et al. Acceptability trails with ready to use food in rural area. National Institute of Nutrition, Indian Council of Medical Research Hyderabad. PMID- 1291497 . 1992 Dec. ; 29(12): 1513-18.

14. Khokar A, Singh $S$, et al. A study of malnutrition among children aged 6mths- 2yrs in Delhi. Indian Journal of Medicine . 2003; Volume 57(7): 286-289.

15. Bhanderi D, Choudhary SK. Epidemiological Study of Health \& Nutritional Status of Under-five children in semi-urban community of Gujarat. Indian Journal of Public Health. 2006; 50(4): 213-219.

16. Kumar Sanjeev: Malnutrition in Children of the Backward States of India and ICDS Programme 2005.

17. George KA, Kumar SN, Lal JJ, et al. Anaemia and nutritional Status of Preschool children in Kerala. Indian Journal of Pediatrics. 2000(67).

18. Mishra SK, Bastola SP, Jha B. Biochemical nutritional indicators in children with protein energy malnutrition attending Kanti Children Hospital, Kathmandu, Nepal. Kathmandu University Medical Journal. 1970; 7(2): 129-134, doi: 10.3126/kumj.v7i2.2705. 